\title{
Service readiness for inpatient care of small and sick newborns: what do we need and what can we measure now?
}

Sarah G Moxon"1 Tanya Guenther², Sabine Gabrysch ${ }^{3}$, Christabel Enweronu-Laryea ${ }^{4}$, Pavani K Ram ${ }^{5,6}$, Susan Niermeyer ${ }^{5,7}$, Kate Kerber ${ }^{2}$, Cally J Tann ${ }^{1,8}$, Neal Russell ${ }^{1}$, Lily $\mathrm{Kak}^{5}$, Patricia Bailey ${ }^{9}$, Sasha Wilson $^{8}$, Wenjuan Wang ${ }^{10}$, Rebecca Winter $^{10}$, Liliana Carvajal-Aguirre ${ }^{11}$, Hannah Blencowe ${ }^{1}$, Oona Campbell ${ }^{1}$, Joy Lawn ${ }^{1}$

\footnotetext{
${ }^{1}$ Maternal, Adolescent, Reproductive and Child Health (MARCH) Centre, London School of Hygiene and Tropical Medicine (LSHTM), London, UK

${ }^{2}$ Saving Newborn Lives, Save the Children, Washington, D.C., USA

${ }^{3}$ Institute of Public Health, Heidelberg University, Heidelberg, Germany

${ }^{4}$ College of Health Sciences, University of Ghana, Accra, Ghana

${ }^{5}$ USAID, Washington, D.C., USA

${ }^{6}$ University at Buffalo, Buffalo, New York, USA

${ }^{7}$ University of Colorado, Aurora, Colorado, USA

${ }^{8}$ University College London Hospital, London, UK

${ }^{9}$ Averting Maternal Death and Disability (AMDD),

New York, New York, USA

${ }^{10}$ The DHS Program-ICF, Rockville, Maryland, USA

${ }^{11}$ UNICEF, New York, New York, USA
}

\section{Correspondence to:}

Sarah G Moxon

London School of Hygiene and Tropical

Medicine

Keppel Street

London, WC1E 7HT

United Kingdom

sarah.moxon@Ishtm.ac.uk
Background Each year an estimated 2.6 million newborns die, mainly from complications of prematurity, neonatal infections, and intrapartum events. Reducing these deaths requires high coverage of good quality care at birth, and inpatient care for small and sick newborns. In low- and middle-income countries, standardised measurement of the readiness of facilities to provide emergency obstetric care has improved tracking of readiness to provide care at birth in recent years. However, the focus has been mainly on obstetric care; service readiness for providing inpatient care of small and sick newborns is still not consistently measured or tracked.

Methods We reviewed existing international guidelines and resources to create a matrix of the structural characteristics (infrastructure, equipment, drugs, providers and guidelines) for service readiness to deliver a package of inpatient care interventions for small and sick newborns. To identify gaps in existing measurement systems, we reviewed three multi-country health facility survey tools (the Service Availability and Readiness Assessment, the Service Provision Assessment and the Emergency Obstetric and Newborn Care Assessment) against our service readiness matrix.

Findings For service readiness to provide inpatient care for small and sick newborns, our matrix detailed over 600 structural characteristics. Our review of the SPA, the SARA and the EmONC assessment tools identified several measurement omissions to capture information on key intervention areas, such as thermoregulation, feeding and respiratory support, treatment of specific complications (seizures, jaundice), and screening and follow up services, as well as specialised staff and service infrastructure.

Conclusions Our review delineates the required inputs to ensure readiness to provide inpatient care for small and sick newborns. Based on these findings, we detail where questions need to be added to existing tools and describe how measurement systems can be adapted to reflect small and sick newborns interventions. Such work can inform investments in health systems to end preventable newborn death and disability as part of the Every Newborn Action Plan. 
The first 28 days of life, the newborn period, represents the time of highest risk in the human lifecycle. In 2016, an estimated 2.6 million newborns died [1], mainly of complications of prematurity (35\%), infections (23\%), and intrapartum complications leading to birth injury (24\%) [1,2]. Preventing deaths from these causes requires a combined health systems approach [3] along the continuum of care. This approach should deliver routine newborn care for all babies (cleanliness, thermal care and support for breastfeeding), newborn resuscitation and prevention of mother to child transmission of HIV (PMTCT) for all babies who need it $[4,5]$; and timely provision of quality inpatient care for babies born small and sick $[6,7]$

Many low birth weight newborns, especially preterm infants, and those born small for gestational age, require support to feed and maintain their temperature. In addition, preterm newborns face increased risks of respiratory problems, infections and jaundice [8]. Even amongst those born at full term, significant numbers of newborns suffer from systemic infections, neonatal encephalopathy, pathological jaundice and congenital abnormalities, with high mortality risk in the absence of care [8]. "Small and sick newborns", therefore, includes all those babies who require inpatient (facility-based) care to survive. The care that small and sick newborns require is not an individual intervention, but a package made up of multiple interventions. Previous work has discussed the specific evidence-based interventions that comprise this package of care $[3,8,9]$, which are displayed in Figure 1.

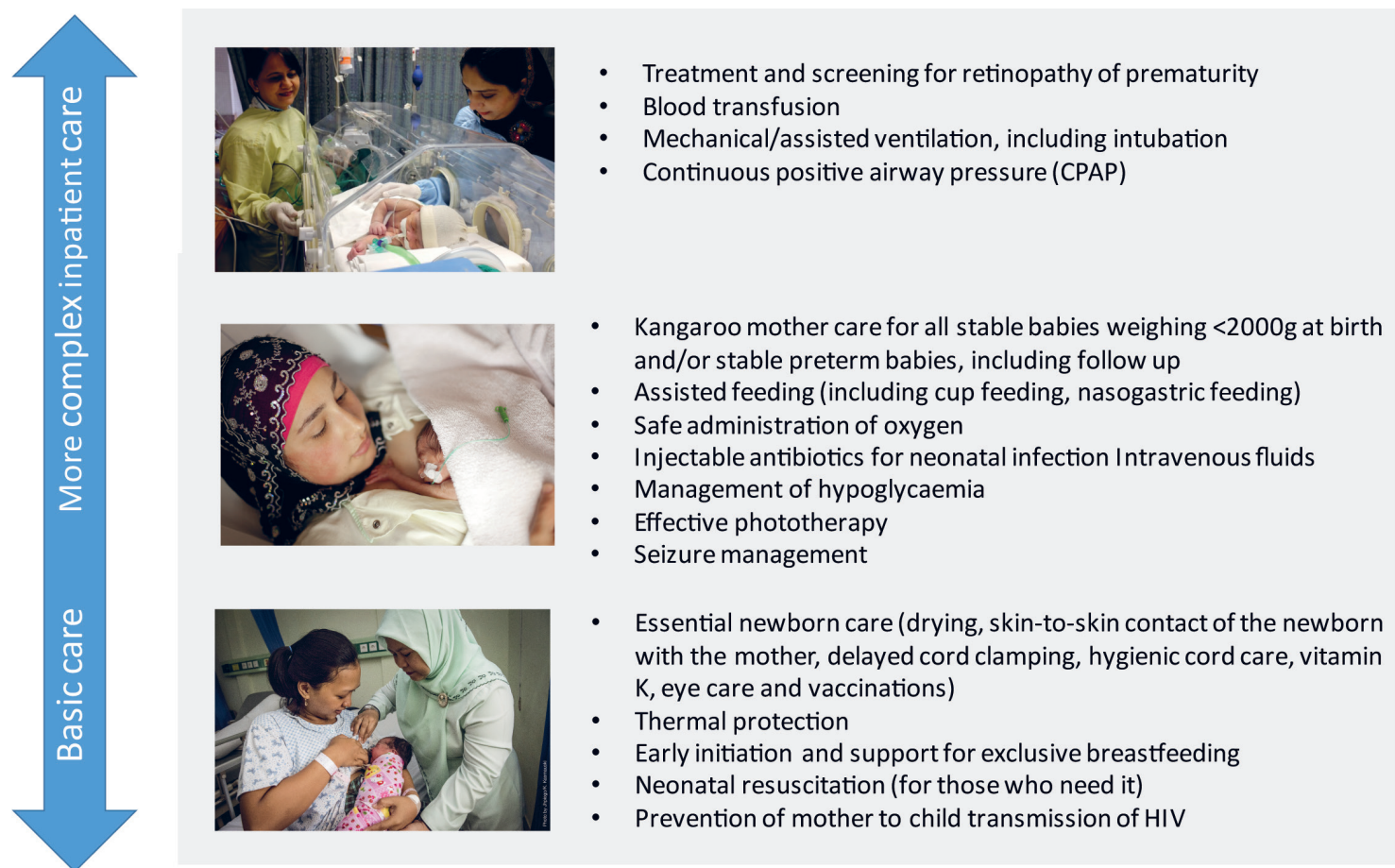

Figure 1. Evidence-based newborn care interventions from basic to complex care. There are additional evidence-based interventions for newborns that should be included in the antenatal period - antenatal corticosteroids and antibiotics for preterm premature rupture of membranes - and follow-up processes that would fall outside of the newborn period and be linked to paediatric services. Figure adapted from [8]. Photo credit (from top to bottom) Ayesha Vellani/Save the Children, OEFCNI, JHPIEGO.

Delivery of interventions to small and sick newborns requires health facilities that are prepared, which is termed as "service readiness". The underpinning principle to service readiness is based on traditional quality of care frameworks, such as that conceived by Donabedian (Figure 2). The framework refers to the structures (the necessary infrastructure, equipment, drugs, health providers and guidelines); and processes (actions performed by health professionals with requisite training and skills) that are needed to provide a package of care [8]. When all of the components of the structural domain are in place, it allows for improvements in clinical processes, which in turn lead to improvements in patient outcomes [10-12]. 


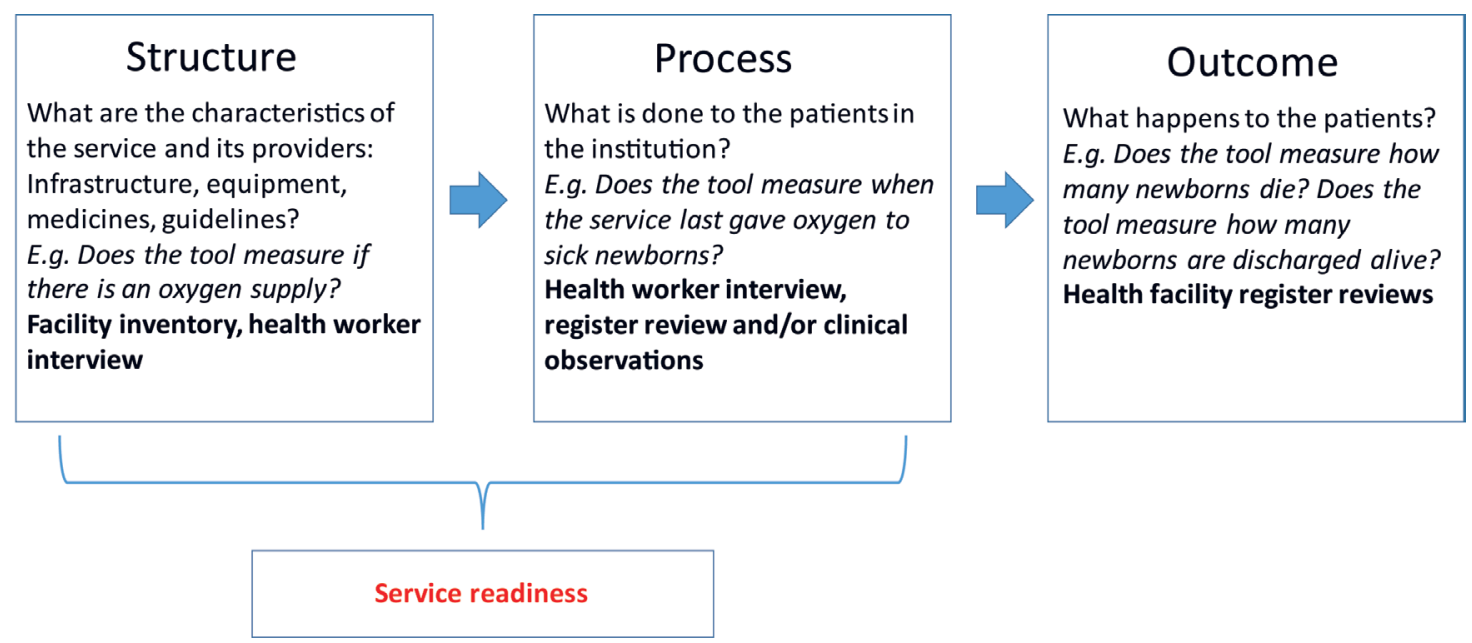

Figure 2. The Donabedian framework applied as a construct to map health facility assessment tools.

To achieve service readiness, the structures not only need to be present, but maintained, re-stocked and updated (eg, equipment requires maintenance, supplies require re-stocking, guidelines require updating) and staff continually trained and supervised. To deliver a quality package of care, therefore, requires strong health systems with the capacity to monitor and track service readiness and react appropriately to service needs.

Evidence from The Lancet Every Newborn Series [13] informed the design of the Every Newborn Action Plan, a multi-partner initiative launched in 2014, backed by a World Health Assembly Resolution. Every Newborn aims to end preventable newborn deaths and stillbirths, with national targets of $\leq 12$ neonatal deaths per 1000 live births and $\leq 12$ stillbirths per 1000 total births by 2030 [7]. To achieve these targets, Every Newborn partners acknowledge a need to improve the measurement of care at birth, and to better track coverage, quality, and equity of care for small and sick newborns around the time of birth [14]. A dedicated sub-group - Every Newborn metrics - focuses on improving the measurement of interventions [14], and has a work stream focused on service readiness for inpatient care of small and sick newborns [9].

Currently, national and facility-based health information systems in low- and middle-income countries collect few data on service readiness for small and sick newborns [13-15], in contrast with child health programmes, notably immunisation, HIV and malaria [16]. Data are sparse in sub-Saharan Africa and parts of Asia where access to care for small and sick newborns is the lowest, and where many facilities need targeted efforts to strengthen services $[8,14]$.

Data from functional routine national health management information systems (HMIS) and logistics management systems (LMIS) are able, in principle, to capture service readiness in a sustainable way, but the content and quality of data in national HMIS are variable in practice. This means many lowand middle-income countries depend on periodic evaluations, such as nationally representative facility surveys or censuses, as a key source of health information to monitor the readiness of the health system to provide facility-based care $[14,17,18]$. These surveys or censuses are referred to as health facility assessments.

The most common health facility assessment tools are the Demographic and Health Survey Programme's Service Provision Assessment (SPA), the WHO Service Availability and Readiness Assessment (SARA) [19,20], and the EmONC assessments, currently managed by Averting Maternal Death and Disability (AMDD) [21] in collaboration with UNFPA [22]. The content of these tools with regards to service readiness specifically for inpatient care of small and sick newborns has not previously been systematically evaluated.

Our overall aim was to review the current health facility assessment tools' ability to capture service readiness for inpatient care of small and sick newborns. 
The specific objectives of this article are to:

1. Create a standardised matrix of the structural components (infrastructure, equipment, drugs, providers and guidelines) required to deliver inpatient care for small and sick newborns.

2. Compare the components of this standardised matrix against what is currently measured by widely used multi-country health facility survey tools (SPA, SARA, EmONC assessment) and identify gaps in measurement of the structural and process domains.

3. Synthesise these findings to provide recommendations on how to improve measurement of service readiness for inpatient care of small and sick newborns.

\section{METHODS}

\section{Conceptual framework for service readiness}

We applied the Donabedian framework $[10,11]$ as a construct to map service readiness for small and sick newborns (Figure 2).

For the first objective, we mapped the structural domain of the framework and identified the infrastructure, equipment, drugs, health providers and guidelines required to deliver inpatient care for small and sick newborns. The second domain in the framework (process) links structures and outcomes, and is dealt with in objective 2 .

\section{Objective 1: Create a standardised matrix of structural components}

\section{Development of matrix of service readiness requirements for inpatient care of small and sick newborns}

We listed a total of 17 newborn interventions based on work done previously as part of the Every Newborn metrics process $[5,8,23]$ (Figure 1). All newborn interventions were included for this exercise, including essential newborn care, based on the rationale that small and sick newborns will require these basic interventions in addition to inpatient care $[8,9]$.

We organised the matrix by six areas: 1) labour and delivery room 2) place of care for small and sick newborns 3) pharmacy/medicines, 4) human resources/providers, 5) laboratory \& blood bank and 6) referral service. We organised interventions by whether they occur in the labour and delivery room or the neonatal unit (or both). Human resources and pharmacy were allocated as a separate area given that providers and drugs will be needed in multiple places of care. Given that most of the guidelines reviewed included information or guidance on referral systems and the associated structural components, we included referral system as a separate "area". Finally, given the wide variation in laboratory systems, we separated the laboratory and blood bank by capacity to perform certain tests and actions, rather than an itemised list of components or equipment.

We searched for existing published guidelines for all the newborn interventions, including relevant newborn and paediatric guidelines available on the WHO website. Where no WHO guideline existed, we consulted relevant resources developed by UNICEF and other partners, including resources from international professional associations, such as the American Academy of Paediatrics and Royal College of Paediatrics and Child Health. To ensure consistency with other areas of care, we also reviewed the interagency list of medical devices for essential interventions for reproductive, maternal, newborn, and child health [24], a master list created for newborn health in humanitarian settings by the Inter-Agency Working Group on Reproductive Health in Crises (IWAG), UNICEF and Save the Children [25] and the latest version of the WHO model essential drugs list [26]. See Table 1 for a list of the guidelines and resources used for this review.

Within each area of the matrix, where equipment items recurred (eg, components required for more than one intervention such as linen, gauze, swabs, weighing scale) we included these under general items for either the labour and delivery room or place of care for small and sick newborns. We were then able to populate the matrix with the specific components required to deliver the interventions for small and sick newborns. 
Table 1. Resource materials and guidelines reviewed for newborn interventions

WHO early essential newborn care: Clinical practice pocket guide

Essential newborn care, thermal protection, early initiation and support for exclusive breastfeeding Newborn Care: A guide for essential practice

UNICEF: Baby Friendly Hospital Initiative (BFHI)
Year pubushed

2014

2015

WHO Integrated management of pregnancy and childbirth: Pregnancy, Childbirth, Postpartum and

WHO Interagency list of priority medical devices for essential interventions for reproductive, maternal, newborn and child health

WHO guidelines on basic newborn resuscitation

2015

2012

2015

Helping Babies Breathe Resources

Neonatal resuscitation

WHO guidelines on managing comp

WHO guidelines on managing newborn problems: a guide for doctors, nurses and midwives

WHO guideline update on HIV and infant feeding

WHO guidelines on antiretroviral drugs for treating pregnant women and preventing HIV infection in infants

Médecins sans Frontières: Neonatal Care Guidelines

Essential care for small babies

WHO kangaroo mother care: A practical guide

2012

Prevention of mother to child transmission of HIV

WHO guidelines on optimal feeding of low birth-weight infants in low- and middle-income countries

UNHCR operational guidelines on improving newborn health in refugee operations

UNICEF toolkit for setting up special care newborn units, stabilisation units and newborn care corners

WHO recommendations on interventions to improve preterm birth outcomes

WHO pocket book of hospital care for children

2010

2016

2015

2003

premature babies, including

follow up, alternative feeding

(cup feeding and nasogastric

feeding)

Injectable antibiotics for neonatal infections, hypoglycaemia management, effective phototherapy, seizure management, administration of oxygen

Treatment and screening for retinopathy of prematurity*

Blood transfusion, Mechanical ventilation and continuous positive airway pressure

WHO pocket book of hospital care for children

2013 (CPAP)

* No current WHO guidelines available; recent guidelines recommended by ROP experts from India and UK selected for review.

\section{Objective 2: Compare the components of this standardised matrix against widely used multi-country health facility survey tools (SPA, SARA, EmONC assessment) and identify gaps in measurement of structural and process domains}

We obtained the latest versions of the SARA (version 2.2, revision July 2015) [20] and the SPA (revised 2012) [27] from their websites. The EmONC assessment tool was being revised at the time of the study and we obtained the version undergoing field-testing from AMDD in July 2016.

We reviewed the SARA core questionnaire tool, the SPA health facility inventory and health worker interview, and the latest versions of the relevant modules from the EmONC assessment, (Module 1: Identification of facility and infrastructure; Module 2: Human Resources; Module 3: Essential drugs, equipment and supplies; Module 5: EmONC interventions; and Module 7: Provider knowledge and competency for maternal \& newborn care)

We compared the content of each of the tools to the structural components in our matrix. To identify gaps in structural components we checked:

- Does the tool measure the infrastructure, equipment, drugs, health providers and/or guidelines needed to provide the interventions?

Many of the tools are designed to also measure aspects of the process domain in the service readiness framework (Figure 2). Therefore, measurement of regular practice or training was considered as a proxy measurement of the process domain for service readiness (as it looks at what is regularly done to patients 
in the institution). For each of the 17 interventions included in the package of care (Figure 1), we also checked:

- Does the tool measure whether staff are given any training to provide the intervention?

- Does the tool measure if the intervention is regularly performed?

The first author (SM), conceptualised the matrix and completed the review of each tool. The matrix was then verified for completeness by practicing neonatologists and nurses with experience in neonatal care in Ghana, Nigeria and co-author practicing neonatal clinicians with experience in India, Malawi, Uganda, United Kingdom and United States.

The review of the health facility assessment tools was verified by a representative of the lead agency for the EmONC assessment and the SPA to ensure the findings were consistent with the most recent versions of the tool.

\section{RESULTS}

\section{Objective 1: Create a standardised matrix of structural components}

We mapped a total of 654 service readiness items for inpatient care of small and sick newborns to provide 17 interventions. This included a total 167 structural items in the labour and delivery room and 266 in the place for small and sick newborn care (or neonatal unit). We listed a total of 33 different potential providers, 114 essential newborn drugs and medicines. A summary list of the international resource materials and guidelines available for care of small and sick newborns used for this objective is included in Table 1. The essential drug list is shown in Table 2. The complete matrix is available in the supplementary material (Table S1 in Online Supplementary Document).

Table 2. Example minimum drug list for inpatient care of small and sick newborns showing rationale for use in newborns and summary of the Service Provision Assessment (SPA), Service Availability and Readiness Assessment (SARA) and Emergency Obstetric and Newborn Care (EmONC) Assessment tools and Essential Medicines list*

\begin{tabular}{|c|c|c|c|c|c|}
\hline Drug name & SPA & SARA & EMONC & EML & Drug DESGRIPTION/USE \\
\hline \multicolumn{6}{|l|}{ Antibiotics: } \\
\hline Amoxicillin (oral suspension) & $\mathrm{Y}$ & $\mathrm{Y}$ & $\mathrm{Y}$ & $\mathrm{Y}$ & Penicillin antibacterial for neonatal infections \\
\hline Amoxicillin (injection) & & & $\mathrm{Y}$ & $\mathrm{Y}$ & Penicillin antibacterial for serious neonatal infections \\
\hline Amikacin (IV or IM) & & & & Y & $\begin{array}{l}\text { Aminoglycoside antibacterial; alternative treatment of opthalmia } \\
\text { neonatorum }\end{array}$ \\
\hline Ampicillin (IV or IM) & $\mathrm{Y}$ & $\mathrm{Y}$ & $\mathrm{Y}$ & $\mathrm{Y}$ & Penicillin antibacterial for serious neonatal infections \\
\hline Ampicillin (oral) & & & & & Penicillin antibacterial for neonatal infections \\
\hline Azithromycin (oral) & $\mathrm{Y}$ & $\mathrm{Y}$ & & $\mathrm{Y}$ & Macrolide antibacterial for P-PROM (maternal use) \\
\hline $\begin{array}{l}\text { Benzathine benzylpenicillin (benzathine } \\
\text { penicillin G) (IM) }\end{array}$ & Y & Y & & Y & Penicillin antibacterial for treatment of congenital syphilis \\
\hline Benzylpenicillin (Penicillin G) (IV or IM) & $\mathrm{Y}$ & & $\mathrm{Y}$ & $\mathrm{Y}$ & Penicillin antibacterial for serious neonatal infections \\
\hline Cefalexin (oral suspension) & & & & Y & $\begin{array}{l}\text { First generation cephalosporin used in newborns for skin and soft tissue } \\
\text { infections }\end{array}$ \\
\hline Cefotaxime (IV or IM) & & & Y & Y & $\begin{array}{l}\text { First generation cephalosporin with broad spectrum for treatment of } \\
\text { serious neonatal infections }\end{array}$ \\
\hline Ceftriaxone (IV or IM) & Y & Y & $\mathrm{Y}$ & & $\begin{array}{l}\text { Third generation cephalosporin for neonatal infections, genital gonococcal } \\
\text { and/or chlamydial infection }\end{array}$ \\
\hline Ciprofloxacin (injection) & & & & Y & $\begin{array}{l}\text { Second generation fluoroquinolone antibacterial sometimes used as } \\
\text { second line treatment }\end{array}$ \\
\hline Ciprofloxacin (oral) & Y & Y & & $\mathrm{Y}$ & $\begin{array}{l}\text { Second generation fluoroquinolone antibacterial for treatment of bacterial } \\
\text { diarrhoea }\end{array}$ \\
\hline Clindamycin (IV) & & & $\mathrm{Y}$ & Y & $\begin{array}{l}\text { Lincosamide antibacterial, second line treatment (eg, streptococcal or soft } \\
\text { tissue infections) }\end{array}$ \\
\hline Co-amoxiclav (oral suspension) & & & $\mathrm{Y}$ & & Penicillin antibacterial, can be used where no IV access \\
\hline Co-amoxiclav (injection) & & & & & Penicillin antibacterial used for neonatal skin infections \\
\hline Cotrimoxazole (oral) & $\mathrm{Y}$ & $\mathrm{Y}$ & & & Combined antibacterial for prophylactic treatment of HIV \\
\hline Erythromycin (oral) & $\mathrm{Y}$ & & $\mathrm{Y}$ & $\mathrm{Y}$ & Macrolide antibacterial for P-PROM (maternal use) \\
\hline Flucloxacillin (IV/IM) (cloxacillin) & & & $\mathrm{Y}$ & $\mathrm{Y}$ & Penicillin antibacterial treatment for neonatal sepsis \\
\hline
\end{tabular}


Table 2. Continued

\section{Drug name}

SPA SARA EMONC EML

\begin{tabular}{lcccc} 
Flucloxacillin (oral) & & & Y & Y \\
\hline Gentamicin (IM or IV) & Y & Y & Y & Y \\
\hline Isoniazid (oral) & Y & Y & & Y \\
\hline Kanamycin & & & & Y \\
\hline Metronidazole (IV) & Y & Y & Y & Y \\
\hline Metronidazole (oral) & Y & Y & & Y \\
\hline Procaine benzylpenicillin (IM) & & Y & Y & Y \\
\hline Tetracycline 1\% eye ointment & Y & Y & Y & Y \\
\hline
\end{tabular}

\section{Anticonvulsants:}

Diazepam (oral/NG)

Diazepam emulsion (IV)

Midazolam (oral solution)

Paraldehyde (rectal)

Phenobarbital (IV or IM)

Phenobarbital (oral)

Phenytoin (IV)

Emergency drugs:

\begin{tabular}{|c|c|c|c|c|}
\hline Adrenaline/epinephrine (IV) & $\mathrm{Y}$ & $\mathrm{Y}$ & $\mathrm{Y}$ & $\mathrm{Y}$ \\
\hline Aminophylline & & & $\mathrm{Y}$ & \\
\hline Atropine (injection) & & $\mathrm{Y}$ & $\mathrm{Y}$ & $\mathrm{Y}$ \\
\hline Calcium gluconate (injection) & $\mathrm{Y}$ & $\mathrm{Y}$ & $\mathrm{Y}$ & $\mathrm{Y}$ \\
\hline Hydrocortisone (injection) & $\mathrm{Y}$ & & $\mathrm{Y}$ & $\mathrm{Y}$ \\
\hline Magnesium sulphate (IV) & $\mathrm{Y}$ & $\mathrm{Y}$ & $\mathrm{Y}$ & $\mathrm{Y}$ \\
\hline Naloxone (IV) & & & $\mathrm{Y}$ & $\mathrm{Y}$ \\
\hline
\end{tabular}

\section{Analgesics:}

Ibuprofen (IV)

Morphine (IV)

Morphine (oral)

Paracetamol (oral)

Paracetamol (suppository)

Paracetamol (injection)

\section{Corticosteroids:}

\begin{tabular}{llllll} 
Corticosteroids: & & & & \\
\hline Betamethasone (IM) & Y & Y & Y & \\
\hline Dexamethasone (IM) & Y & Y & Y & Y
\end{tabular}

\section{IV fluids:}

Calcium gluconate 10\%

Dextrose $10 \%$ with normal saline

Dextrose/glucose 5\%

Dextrose/glucose 10\%

Potassium chloride (KCl) 7.5\%, 10\%,

$15 \%$

$\begin{array}{cccc}\text { Y } & Y & & \mathrm{Y} \\ \mathrm{Y} & & \mathrm{Y} & \mathrm{Y} \\ \mathrm{Y} & \mathrm{Y} & \mathrm{Y} & \mathrm{Y} \\ & \mathrm{Y} & \mathrm{Y} & \mathrm{Y}\end{array}$

Sodium bicarbonate

Sodium chloride 0.9\%

Ringer's lactate

Water for injection
Y Analgesic sometimes used in newborns for closing patent ductus arteriosus

\section{Drug DESGRIPTION/USE}

Penicillin antibacterial. Can be used in newborns as follow on from intravenous flucloxacillin

Aminoglycoside antibacterial used for treatment of neonatal sepsis

Antituberculous antibacterial used occasionally for congenital TB

Aminoglycoside antibacterial; alternative to gentamicin

Antiprotozoal antibacterial used for neonatal meningitis and/or anaerobic bacterial infections

Antiprotozoal antibacterial used for neonatal meningitis and/or anaerobic bacterial infections

Penicillin antibacterial used for congenital syphilis

Prophylactic topical antibiotic used to prevent bacterial (eg, chlamydial, gonococcal) neonatal conjunctivitis

Y Sedative, anticonvulsant, muscle relaxant mostly used for neonatal tetanus Sedative, anticonvulsant, muscle relaxant, used for neonatal tetanus

Y Sedative, anticonvulsant used for seizures Anticonvulsant for seizures

First line anticonvulsant for tonic clonic and partial seizures First line anticonvulsant for tonic clonic and partial seizures Anticonvulsant for tonic clonic and partial seizures

Sympathomimetic for cardiopulmonary arrest used for advanced neonatal resuscitation Methylzanthine used to prevent apnoeic attacks in premature newborns Parasympatholytic, antispasmodic used for intubation Used for hypocalcaemic seizures and hyperkalaemia Steroidal anti-inflammatory used for hypotension or severe bronchopulmonary dysplasia Inorganic salt compound, maternal use in preterm labour, protective against cerebral palsy

Specific opioid antagonist for respiratory depression in newborns

Y Centrally acting opioid analgesic for severe pain, sedation and intubation

$\mathrm{Y} \quad$ Used for severe pain

Analgesic for minor pain

$\mathrm{Y} \quad$ Analgesic for minor pain

Analgesic for minor pain. Also used for newborns for closing patent ductus arteriosus.

Not used in newborns; used in mothers with threatened preterm labour $<34$ weeks gestation for fetal lung maturation

Not used in newborns; used in mothers with threatened preterm labour $<34$ weeks gestation for fetal lung maturation

Supplement used to treat calcium deficiency. Dependent on programme context - careful monitoring required Solution used for maintainance fluid therapy Solution used as vehicle for administration of IV drugs

Solution for treatment of hypoglycaemia and maintenance fluid therapy on first day of life for sick babies who cannot feed

Y Solution only to be used in contexts where monitoring of potassium levels is available.

Y Solution used to dissolve artesunate

Solution used as a vehicle for administration of IV/parenteral drugs, fluid replacement and flushing IV lines

Compound solution for severe dehydration/hypovolaemia can be added to dextrose/glucose for a mix Sterile water for mixing drugs 
Table 2. Continued

Anti-malarials:

\begin{tabular}{llllll}
\hline Artesunate (IV or IM) & Y & Y & & Y & First line treatment for neonatal malaria \\
\hline Artesunate (rectal) & Y & Y & Y & Neonatal malaria treatment if IV/IM access not available \\
\hline Arthemeter (IM) & & & & Y & Second line treatment for neonatal malaria \\
\hline $\begin{array}{l}\text { Artemisinin-based combined therapy } \\
\text { (oral) }\end{array}$ & Y & Y & Y & Y & Second line anti-malarial treatment followed by ACT \\
\hline
\end{tabular}

Antiretrovirals (may vary depending on national HIV guidelines):

\begin{tabular}{llllll}
\hline Azidothymidine/Zidovudine (AZT) (oral) & Y & Y & Y & Y & Antiretroviral \\
\hline Lamivudine & Y & Y & Y & Y & Antiretroviral \\
\hline Nevirapine (NVP) (oral) & Y & Y & Y & Y & Antiretroviral
\end{tabular}

\section{Other drugs:}

Aciclovir (IV)

Acyclovir 3\% topical eye ointment

Anti-Rho (D) immune globulin

(injection) *

Caffeine citrate (oral)

Caffeine citrate (IV)

Chlorhexidine digluconate $7.1 \%$ gel

(delivering 4\% chlorhexidine)

Domperidone

Ethambutamol (oral)

Ferrous fumerate (oral)

Folic acid

Fluconazole (IV)

Fluconazole (oral)

Furosemide (IV)

Furosemide (oral)

Glycerin chip

Hepatitis B immune globulin (HBIG)

Human milk fortifier

\begin{tabular}{|c|c|c|c|c|c|}
\hline \multirow[b]{2}{*}{$\begin{array}{l}\text { Insecticxide treated bed nets (in malaria } \\
\text { endemic areas) }\end{array}$} & \multirow[b]{2}{*}{ Y } & \multirow[b]{2}{*}{ Y } & \multirow{2}{*}{\multicolumn{2}{|c|}{ Y }} & \multirow[b]{2}{*}{ For mother's beds in KMC ward and for discharge home } \\
\hline & & & & & \\
\hline Lidocaine solution & $\mathrm{Y}$ & $\mathrm{Y}$ & $\mathrm{Y}$ & $\mathrm{Y}$ & Local anaesthetic \\
\hline $\begin{array}{l}\text { Miconazole cream (or equivalent eg, } \\
\text { gentian violet) }\end{array}$ & Y & & & Y & Topical antifungal for candida dermatitis used for nappy area \\
\hline Multivitamin & & & & & Containing zinc, vitamin A etc. \\
\hline Nystatin (oral solution) & Y & & Y & Y & $\begin{array}{l}\text { Topical antifungal for oropharyngeal candidiasis used prophylactically } \\
\text { with antibiotic treatment }\end{array}$ \\
\hline Nystatin cream & & & & $\mathrm{Y}$ & Topical antifungal \\
\hline Omeprazole (IV) & $\mathrm{Y}$ & & & $\mathrm{Y}$ & Acid blocker for gastro-oesophageal reflux \\
\hline Omeprazole (oral) & $\mathrm{Y}$ & & & $\mathrm{Y}$ & Acid blocker for gastro-oesophageal reflux \\
\hline Oral rehydration solution & Y & Y & Y & Y & $\begin{array}{l}\text { Powder to mix with drinking water for oral rehydration; breastmilk } \\
\text { feeding should be encouraged }\end{array}$ \\
\hline Oxygen supply & & & & $\mathrm{Y}$ & Medical inhalation gas for treatment of respiratory distress \\
\hline Phosphate and calcium supplements & & & & & Supplementation \\
\hline Potassium Chloride $(1 \mathrm{mmol} / \mathrm{ml})$ (oral) & & & & $\mathrm{Y}$ & Powder solution for maintainance oral potassium replacement \\
\hline Pyridoxine (oral) & & & & $\mathrm{Y}$ & Preventive therapy for tuberculosis \\
\hline Pyrazinamide (oral) & $\mathrm{Y}$ & $\mathrm{Y}$ & & $\mathrm{Y}$ & First line oral anti-tuberculolous drug \\
\hline Ranitidine (IV) & & & & $\mathrm{Y}$ & Antacid drug for gastro-oesophageal reflux \\
\hline Ranitidine (oral) & & & & $\mathrm{Y}$ & Antacid drug for gastro-oesophageal reflux \\
\hline Rifampicin (oral) & $\mathrm{Y}$ & $\mathrm{Y}$ & & $\mathrm{Y}$ & First line oral anti-tuberculolous drug \\
\hline Sucrose $30 \%$ (oral) & & & & & $\begin{array}{l}\text { Non-pharmacological pain management for minor procedures (eg, } \\
\text { cannulation) }\end{array}$ \\
\hline Tetanus immunoglobulin (HTIG) (IM) & & & $\mathrm{Y}$ & $\mathrm{Y}$ & Anti-tetanus immunoglobulin for treatment of neonatal tetanus \\
\hline Vitamin B6 (pyridoxine) (IV or IM) & & & & & Vitamin for B6 deficiency \\
\hline Vitamin D & & & & & Supplementation. \\
\hline Vitamin Kl (Phytomenadione) (IM or IV) & & & Y & Y & $\begin{array}{l}\text { Vitamin and anti-haemorrhagic for prophylactic treatment of } \\
\text { haemorrhagic disease of the newborn }\end{array}$ \\
\hline
\end{tabular}

Y Antiviral used for herpes

Y Antiviral active against herpes virus used to prevent neonatal herpes keratitis in babies born to mother with genital herpes

To prevent Rhesus disease (haemolytic disease of the newborn), given to mothers

Y Preventive treatment for apnoea

Y Preventive treatment for apnoea, oral preferred over IV

Y Topical treatment of omphalitis

Anti-reflux drug for gastro-oesophageal reflux

First line oral anti-tuberculolous drug

Oral suspension used for preterm neonates to prevent iron deficiency

Oral suspension used for folate supplementation

Antifungal drug used in newborns over 1 week

Antifungal drug

Y Diuretic used for chronic lung disease, oedema in advanced settings

Diuretic

Suppository used in newborns to stimulate stooling

Treatment of Hepatitis B in neonates Fortifier, adds protein, calories and micronutrients to expressed breastmilk

(1) 
Table 2. Continued

\begin{tabular}{|c|c|c|c|c|c|}
\hline Drug name & SPA & SARA & EMONC & EML & Drug DESGRIPTION/USE \\
\hline Water based lubricant & & & & & For inserting suppositories and/or other procedures. \\
\hline Zinc oxide cream & & & & & Topical for nappy/diaper rash \\
\hline \multicolumn{6}{|l|}{ Vaccines: } \\
\hline BCG vaccine & $\mathrm{Y}$ & $\mathrm{Y}$ & $\mathrm{Y}$ & $\mathrm{Y}$ & Prevention of TB \\
\hline Diptheria & $\mathrm{Y}$ & $\mathrm{Y}$ & & $\mathrm{Y}$ & Prevention of diptheria \\
\hline Pertussis vaccine & $\mathrm{Y}$ & $\mathrm{Y}$ & & $\mathrm{Y}$ & Prevention of pertussis \\
\hline $\begin{array}{l}\text { Haemophilus influenzae type b (Hib) } \\
\text { vaccine }\end{array}$ & Y & $\mathrm{Y}$ & & Y & Prevention of haemophilis influenzae type B \\
\hline Hepatitis B vaccine & Y & Y & & Y & $\begin{array}{l}\text { Prevention of hepatitis B in countries where perinatal infection is } \\
\text { common, as per vaccination schedule }\end{array}$ \\
\hline Oral poliomyelitis vaccine & $\mathrm{Y}$ & $\mathrm{Y}$ & $\mathrm{Y}$ & $\mathrm{Y}$ & Prevention of poliomyelitis \\
\hline Tetanus toxoid & $\mathrm{Y}$ & Y & $\mathrm{Y}$ & Y & $\begin{array}{l}\text { Prevention of tetanus in wound management, prevention of maternal and } \\
\text { neonatal tetanus in pregnant women }\end{array}$ \\
\hline
\end{tabular}

EmONC - Emergency Obstetric and Newborn Care, SPA - Service Provision Assessment, SARA - Service Availability and Readiness Assessment, EML - Essential Medicines List, IM - intramuscular, IV - intravenous, NG - nasogastric

*Y - measured by the tool.

\section{Objective 2: Compare the components of this standardised matrix against widely used multi-country health facility survey tools (SPA, SARA, EmONC assessment) and identify gaps in measurement of structural and process domains}

The SPA, the SARA and the EmONC assessment tools are summarised in Table 3. All three tools have different purposes, are measured at different intervals, and have different approaches to measurement and sampling.

Table 3. Summary of three multi-country health facility assessment tools: Service Provision Assessment (SPA), Service Availability and Readiness Assessment and Emergency Obstetric and Newborn Care (EmONC) Assessment

\begin{tabular}{|c|c|c|c|}
\hline & Service Provision Assessments (SPA) & $\begin{array}{l}\text { Service Avallabiuty and Readiness Assessment } \\
\text { (SARA) }\end{array}$ & $\begin{array}{l}\text { Emereency Obstetric and Newborn Care (EmONC) } \\
\text { Assessment }\end{array}$ \\
\hline Purpose of tool & $\begin{array}{l}\text { For comprehensive monitoring of a } \\
\text { country's formal health care system; } \\
\text { monitors the overall availability of dif- } \\
\text { ferent facility-based health services in a } \\
\text { country and their readiness to provide } \\
\text { those services }\end{array}$ & $\begin{array}{l}\text { For assessing readiness of facilities using a } \\
\text { standard set of indicators that cover all } \\
\text { main health programmes. Only designed to } \\
\text { assess service readiness (not performance } \\
\text { or client perspectives) }\end{array}$ & $\begin{array}{l}\text { For monitoring and assessment of the avail- } \\
\text { ability, use and quality of routine and emergen- } \\
\text { cy obstetric and newborn care in the formal } \\
\text { health system. }\end{array}$ \\
\hline Organisation(s) & $\begin{array}{l}\text { The Demographic and Health Survey } \\
\text { (DHS) Program, United States Agency } \\
\text { for International Development (USAID) }\end{array}$ & $\begin{array}{l}\text { World Health Organization (WHO), US- } \\
\text { AID }\end{array}$ & $\begin{array}{l}\text { Averting Maternal Death \& Disability (AMDD), } \\
\text { United Nations Population Fund (UNFPA), } \\
\text { United Nations Children's Fund (UNICEF), } \\
\text { WHO. }\end{array}$ \\
\hline Sample & $\begin{array}{l}\text { Sample survey or census of formal sec- } \\
\text { tor health facilities designed to provide } \\
\text { nationally representative results by fa- } \\
\text { cility type, managing authority, and } \\
\text { geographic region. }\end{array}$ & $\begin{array}{l}\text { Sample survey or census of at least } 150 \\
\text { public and private facilities }\end{array}$ & $\begin{array}{l}\text { Census of hospitals and census or sample of } \\
\text { lower-level delivery sites (public and private } \\
\text { facilities). Sample may be random or selection } \\
\text { may be restricted to lower-level facilities that } \\
\text { meet a specific volume of deliveries. }\end{array}$ \\
\hline Modules & $\begin{array}{l}\text { Facility inventory, exit interviews (ante- } \\
\text { natal care, family planning, sick child), } \\
\text { clinical observations (antenatal care, } \\
\text { family planning, sick child), health } \\
\text { worker provider interviews }\end{array}$ & Facility inventory, health worker interview & $\begin{array}{l}\text { Facility inventory, human resources, essential } \\
\text { drugs, equipment and supplies, facility case } \\
\text { summary, Emergency Obstetric Care (EmOC) } \\
\text { signal functions, provider knowledge for mater- } \\
\text { nal and some newborn care \& chart reviews. }\end{array}$ \\
\hline $\begin{array}{l}\text { Numerator for } \\
\text { indicator }\end{array}$ & $\begin{array}{l}\text { Number of facilities ready to provide } \\
\text { MNCH, family planning, HIV/AIDS, } \\
\text { STIs, Malaria, Tuberculosis, basic sur- } \\
\text { gery, non-communicable diseases ser- } \\
\text { vices. }\end{array}$ & $\begin{array}{l}\text { Proportion of health facilities, number of } \\
\text { core medical professionals, proportion of } \\
\text { facilities offering a defined service and the } \\
\text { density and distribution of the facilities }\end{array}$ & $\begin{array}{l}\text { Number of facilities providing EmOC, number } \\
\text { of facilities providing each EmOC signal func- } \\
\text { tions by level of care. }\end{array}$ \\
\hline $\begin{array}{l}\text { Denominator } \\
\text { for indicator* }\end{array}$ & All formal facilities & All facilities, per 10000 population & $\begin{array}{l}\text { All surveyed facilities by level of care; availabil- } \\
\text { ity of EmOC is measured per } 500000 \text { popula- } \\
\text { tion or } 20000 \text { births* }\end{array}$ \\
\hline Timeframe & $\begin{array}{l}\text { 15-18 months to complete fieldwork } \\
\text { and report }\end{array}$ & Variable, but shorter than SPA or EmONC & $\begin{array}{l}\text { 12-18 months to complete field work and re- } \\
\text { port }\end{array}$ \\
\hline Frequency & 4-5 yearly intervals & Designed to be repeated annually & $4-5$ yearly intervals \\
\hline
\end{tabular}

*Discussion is ongoing on whether denominator should measure births or population); expected number of births is the denominator for several other indicators - institutional birth rate, caesarean-section rate, met need for emergency obstetric care. 
Table 4. A summary of the Service Provision Assessment (SPA), Service Availability and Readiness Assessment (SARA) and Emergency Obstetric and Newborn Care (EmONC) assessment tools' capacity to measure structural and process domains of service readiness for newborn interventions in the labour and delivery room

\begin{tabular}{|c|c|c|c|}
\hline \multirow{2}{*}{ INTERVENTION AND COMPONENTS OF STRUCTURAL DOMAIN } & \multicolumn{3}{|c|}{ Heatth Faciltit assesSment tool } \\
\hline & SPA & SARA & EmONC \\
\hline \multicolumn{4}{|l|}{ Immediate/essential newborn care: } \\
\hline Infrastructure & $\mathrm{Y}$ & $\mathrm{Y}$ & $\mathrm{Y}$ \\
\hline Equipment $\&$ drugs & $\mathrm{Y}$ & $\mathrm{Y}$ & $\mathrm{Y}$ \\
\hline Guidelines & & $\mathrm{Y}$ & $\mathrm{Y}$ \\
\hline Training & $\mathrm{Y}$ & $\mathrm{Y}$ & $\mathrm{Y}$ \\
\hline Routine practice & $\mathrm{Y}$ & $\mathrm{Y}$ & $\mathrm{Y}$ \\
\hline \multicolumn{4}{|l|}{ Thermal protection: } \\
\hline Infrastructure & $\mathrm{Y}$ & $\mathrm{Y}$ & $\mathrm{Y}$ \\
\hline \multicolumn{4}{|l|}{ Equipment $\&$ drugs } \\
\hline Guidelines & $\mathrm{Y}$ & $\mathrm{Y}$ & $\mathrm{Y}$ \\
\hline Training & $\mathrm{Y}$ & & \\
\hline Routine practice & $\mathrm{Y}$ & & $\mathrm{Y}$ \\
\hline \multicolumn{4}{|l|}{ Immediate and exclusive breastfeeding: } \\
\hline \multicolumn{4}{|l|}{ Infrastructure } \\
\hline Equipment \& drugs & & & $\mathrm{Y}$ \\
\hline Guidelines & $\mathrm{Y}$ & & $\mathrm{Y}$ \\
\hline Training & $\mathrm{Y}$ & $\mathrm{Y}$ & $\mathrm{Y}$ \\
\hline Routine practice & $\mathrm{Y}$ & $\mathrm{Y}$ & $\mathrm{Y}$ \\
\hline \multicolumn{4}{|l|}{ Resuscitation with bag and mask: } \\
\hline Infrastructure & $\mathrm{Y}$ & $\mathrm{Y}$ & $\mathrm{Y}$ \\
\hline Equipment $\&$ drugs & $\mathrm{Y}$ & $\mathrm{Y}$ & $\mathrm{Y}$ \\
\hline Guidelines & $\mathrm{Y}$ & $\mathrm{Y}$ & $\mathrm{Y}$ \\
\hline Training & $\mathrm{Y}$ & $\mathrm{Y}$ & $\mathrm{Y}$ \\
\hline Routine practice & $\mathrm{Y}$ & $\mathrm{Y}$ & $\mathrm{Y}$ \\
\hline \multicolumn{4}{|l|}{ PMTCT if HIV-positive mother: $\dagger$} \\
\hline Infrastructure & $\mathrm{Y}$ & $\mathrm{Y}$ & $\mathrm{Y}$ \\
\hline Equipment \& drugs & $\mathrm{Y}$ & $\mathrm{Y}$ & $\mathrm{Y}$ \\
\hline Guidelines & $\mathrm{Y}$ & $\mathrm{Y}$ & $\mathrm{Y}$ \\
\hline Training & $\mathrm{Y}$ & $\mathrm{Y}$ & $\mathrm{Y}$ \\
\hline Routine practice & $\mathrm{Y}$ & $\mathrm{Y}$ & $\mathrm{Y}$ \\
\hline
\end{tabular}

EmONC - Emergency Obstetric and Newborn Care, SPA - Service Provision Assessment, SARA - Service Availability and Readiness Assessment

*Y - measured by the tool.

$\uparrow$ May only be applicable in settings with high HIV prevalence.
Table 4 and Table 5 summarise the mapping of the interventions showing the structures and processes currently measured by the SPA, the SARA and the EmONC survey tools, and highlighting gaps in measurement of structural and process domains.

For ease of presentation, and to avoid repetition, we summarise the findings from the review in this section by structural and process domains.

\section{Comparison of the matrix against health facility assessment tools and identification of gaps in measurement of the structural domain}

\section{Infrastructure}

All three tools measured elements of general health facility infrastructure, such as electricity supply, means of communication, referral and transport and availability of water, toilets/latrines and waste disposal.

All tools measure availability of a table or surface for performing resuscitation. However, infrastructural requirements to support essential newborn care both in the labour and delivery room and the postnatal ward, such as space, privacy (screens) for mother to express breastmilk and infrastructure for storage of breastmilk (and whether there is consistent power supply for refrigeration) were not measured by any of the tools. All tools collect details on infrastructure to provide PMTCT.

The SPA measured space for mothers to provide kangaroo mother care (KMC) in its facility inventory, but only the EmONC assessment asked about space allocation for sick newborn care or a special care unit (eg, infrastructure to provide services beyond KMC, such as assisted feeding, thermal protection, fluids and/or oxygen support). As oxygen is a crosscutting infrastructural component needed for several interventions outside of newborn health, all tools measured availability of an oxygen source. However, none of the tools measured the newborn-specific infrastructure that would be needed for safe oxygen therapy. Continuity of electricity and oxygen is especially important for facilities offering care for small and sick newborns who may be dependent on consistent oxygen source and/or electric equipment. None of the tools measured service readiness infrastructure for screening services (for example, developmental milestones, hearing and vision) or follow-up for high-risk infants.

Table 5. A summary of the Service Provision Assessment (SPA), Service Availability and Readiness Assessment (SARA) and Emergency Obstetric and Newborn Care (EmONC) tools' capacity to measure structural and process domain of service readiness for interventions in the newborn inpatient care unit 
Table 5. Continued

Routine practice

$\mathrm{Y}$

Y

Alternative feeding if baby unable to breastfeed (cup feeding and nasogastric feeding):

Infrastructure

Equipment \& drugs

Guidelines

Training

Routine practice

Safe administration of oxygen (including equipment for resuscitation):

Infrastructure

Equipment \& drugs

Guidelines

Training

Routine practice

Intravenous fluids and management of hypoglycaemia:

Infrastructure

Equipment \& drugs

Guidelines

Training

Routine practice

Injectable antibiotics for neonatal infection:

Infrastructure

Equipment \& drugs

Guidelines

Training

Routine practice

Effective phototherapy:

Infrastructure

Equipment \& drugs

Guidelines

Training

Routine practice

Seizure management:

Infrastructure

Equipment \& drugs

Guidelines

Training

Routine practice

Continuous positive airway pressure and assisted/mechanical ventilation:

Infrastructure

Equipment \& drugs

Guidelines

Training

Routine practice

Blood transfusion for newborns:

Infrastructure

Equipment \& drugs

Guidelines

Training

Routine practice

Treatment and screening for retinopathy of prematurity:

Infrastructure

Equipment \& drugs

Guidelines

Training

Routine practice

EmONC - Emergency Obstetric and Newborn Care, SPA - Service Provision Assessment, SARA - Service Availability and Readiness Assessment

*Y - measured by the tool. 
None of the tools measured advanced infrastructure for intensive care for very small and sick newborns, such as that required for mechanical ventilation, newborn blood and/or exchange transfusion, and specialist laboratory infrastructure beyond that needed for obstetric, and some paediatric and adult services.

\section{Equipment}

All tools measured provision of basic equipment for neonatal resuscitation, including smaller-sized face masks and resuscitation bag in the labour and delivery room. None of the tools measured whether resuscitation equipment was available in the room where small and sick newborns are cared for to ensure safety and continuity of care.

Simpler interventions for small newborns, such as assisted feeding (plastic feeding cups and small sized nasogastric tubes) were only measured by the EmONC assessment, and hats or caps (including small sizes) are not consistently measured among the tools.

Phototherapy equipment needed to treat neonatal jaundice was only measured by the EmONC assessment (fluorescent tubes and icterometry). Lower cost phototherapy technologies, such as LED phototherapy devices were not included in any of the tools.

Although the infrastructure for oxygen was measured, most likely for paediatric and adult services, safe delivery of oxygen to newborns requires significant additional equipment items, such as newborn pulse oximetry, neonatal nasal prongs, oxygen-air blenders, low-flow metres and humidifiers, which were not captured by the tools.

Higher level respiratory support for newborns, such as Continuous Positive Airway Pressure (CPAP) ventilation, was not measured by any of the tools. Our matrix shows that for safe delivery of CPAP, beyond the drivers themselves, facilities would require critical emergency equipment in case of pneumothorax such as transilluminators, chest tubes and valves.

Intubation equipment (eg, laryngoscopes blades in small sizes) were measured by the EmONC assessment, but other critical components to support a ventilated newborn were not measured, including the ventilator machine.

\section{Drugs}

The EmONC assessment tool had the most extensive list of drugs and medicines for newborns detailing 106 medicines and drugs for mothers and newborns, but very few of these are specified for newborns. There were several notable omissions of medicines for care at birth within the SPA and SARA, such as vitamin K (SPA only asks whether it is routinely administered).

All three tools measured antibiotic drugs for treating small and sick newborn infections (amoxicillin oral and injection, ampicillin injection and gentamicin injection as a minimum). However, inventories did not specify whether the antibiotic was available in the injectable form, with the appropriate concentrations and diluents (usually water for injection, sodium chloride $0.9 \%$ and glucose $5 \%$ ), or the availability of smaller intravenous cannulas/catheters and syringe drivers. The tools measured standard intravenous fluid preparations, but only EmONC included glucose 10\%, which is most frequently used for neonates. For seizure management, only the EmONC tool measured the first and second line treatments (intravenous phenobarbitone and phenytoin).

Several drugs that might be used for advanced level care, such as procedural sedation and pain relief, were not currently included in any of the tools.

In Table 2 we present an example drug list for inpatient care of small and sick newborns indicating which drugs are measured by each tool and whether these are on the most recent WHO model essential medicines list [26]. This includes the commodities needed for retinopathy of prematurity screening and treatment, such as dilating and anaesthetic eye drops, which are not currently included in existing tools.

\section{Health providers}

There were several notable gaps in measurement of specialist newborn staff. Only the EmONC tool measured specialist staff cadres for newborns (eg, neonatologist) and none of the tools measured specialist neonatal nurses. Allied staff and support staff (eg, social workers, speech therapist) were not measured. None of the tools measured ophthalmologists or related professions that are needed in settings where newborns may require screening and treatment for retinopathy of prematurity, or biomedical engineers for equipment maintenance. 


\section{Guidelines}

Table 1 shows all the guidelines and educational resources used for this review. Some resources cover a number of different interventions. However, there were notable gaps in available guidelines for more complex interventions, such as continuous positive airway pressure, blood transfusion, exchange transfusion, ventilation, and treatment and screening of retinopathy of prematurity.

\section{Identification of gaps in measurement of the process domain to capture service readiness to care for small and sick newborns for each intervention}

Measurement of regular practice or training of health staff in specific interventions was considered as a proxy measurement for the process domain for service readiness as it looks at what is regularly done to patients in the institution.

\section{Regular practice}

All the tools relied on direct health worker reports, the register, or chart reviews to measure whether select interventions were regularly provided for small and sick newborns.

The SPA looked at whether a limited number of interventions relevant to newborns (neonatal resuscitation and corticosteroids for preterm labour) were ever practiced and practiced in the last 3 months. The SPA also included a series of questions on essential care for newborns, but none on inpatient care for small and sick newborns, other than if KMC was practiced in the facility.

The SARA asked whether a limited number of functions were provided in the last 12 months: antibiotics for preterm or prolonged premature rupture of membranes, antenatal corticosteroids, neonatal resuscitation, KMC, and injectable antibiotics.

The EmONC assessment had the most detailed list of newborn interventions for which questions on regular or recent practice were asked (newborn resuscitation, antenatal corticosteroids, antibiotics for preterm premature rupture of membranes, antibiotics for neonatal infections, KMC, administration of oxygen and administration of IV fluids).

The EmONC tool included specific knowledge questions on small and sick newborn care, including a few interventions, such as resuscitation, oxygen therapy and infections.

Table 6 summarises the approaches used by each of the tools to capture regular practice and training.

Table 6. The approach used by Service Provision Assessment (SPA), Service Availability and Readiness Assessment (SARA) and Emergency Obstetric and Newborn Care (EmONC) assessment to measure regular practice and training

\begin{tabular}{|c|c|c|c|c|c|c|}
\hline & \multicolumn{2}{|c|}{ SPA } & \multicolumn{2}{|c|}{ SARA } & \multicolumn{2}{|c|}{ EMONC } \\
\hline & Regular Practice & TrainIng & Regular Practice & Training & Regular PRACTICE & Training \\
\hline Essential newborn care & $\begin{array}{l}\text { Routinely } \\
\text { practiced }\end{array}$ & $\begin{array}{l}\text { Training in last } \\
24 \text { months }\end{array}$ & $\begin{array}{l}\text { Routinely } \\
\text { carried out }\end{array}$ & $\begin{array}{l}\text { Training in last } \\
24 \text { months }\end{array}$ & $\begin{array}{l}\text { Performed in last } 3 \\
\text { months }\end{array}$ & $\begin{array}{l}\text { Ever received } \\
\text { training }\end{array}$ \\
\hline Thermal protection & & $\begin{array}{l}\text { Training in last } \\
24 \text { months }\end{array}$ & & & $\begin{array}{l}\text { As part of essential } \\
\text { newborn care }\end{array}$ & $\begin{array}{l}\text { As part of essential } \\
\text { newborn care }\end{array}$ \\
\hline $\begin{array}{l}\text { Early initiation and support } \\
\text { for exclusive breastfeeding }\end{array}$ & $\begin{array}{l}\text { Routinely } \\
\text { practiced }\end{array}$ & $\begin{array}{l}\text { Training in last } \\
24 \text { months }\end{array}$ & $\begin{array}{l}\text { Routinely } \\
\text { carried out }\end{array}$ & $\begin{array}{l}\text { Training in last } \\
24 \text { months }\end{array}$ & $\begin{array}{l}\text { As part of essential } \\
\text { newborn care }\end{array}$ & $\begin{array}{l}\text { As part of essential } \\
\text { newborn care }\end{array}$ \\
\hline $\begin{array}{l}\text { Neonatal resuscitation with } \\
\text { bag and mask }\end{array}$ & $\begin{array}{l}\text { Ever practiced, } \\
\text { practiced in } \\
\text { last } 3 \text { months }\end{array}$ & $\begin{array}{l}\text { Training in last } \\
24 \text { months }\end{array}$ & $\begin{array}{l}\text { Practiced in } \\
\text { last } 12 \text { months }\end{array}$ & $\begin{array}{l}\text { Training in last } \\
24 \text { months }\end{array}$ & $\begin{array}{l}\text { Performed in last } 3 \\
\text { months }\end{array}$ & $\begin{array}{l}\text { Ever received } \\
\text { training }\end{array}$ \\
\hline $\begin{array}{l}\text { Prevention of mother to child } \\
\text { transmission of HIV }\end{array}$ & $\begin{array}{l}\text { Routinely } \\
\text { practiced }\end{array}$ & $\begin{array}{l}\text { Training in last } \\
24 \text { months }\end{array}$ & $\begin{array}{l}\text { Service is } \\
\text { offered }\end{array}$ & $\begin{array}{l}\text { Training in last } \\
24 \text { months }\end{array}$ & $\begin{array}{l}\text { ARVs given to newborns } \\
\text { in the last } 3 \text { months }\end{array}$ & $\begin{array}{l}\text { Ever received } \\
\text { training }\end{array}$ \\
\hline Kangaroo mother care & Ever practiced & $\begin{array}{l}\text { Training in last } \\
24 \text { months }\end{array}$ & $\begin{array}{l}\text { Practiced in } \\
\text { last } 12 \text { months }\end{array}$ & & $\begin{array}{l}\text { Performed in the last } 3 \\
\text { months }\end{array}$ & $\begin{array}{l}\text { Ever received } \\
\text { training }\end{array}$ \\
\hline $\begin{array}{l}\text { Assisted feeding (cup feeding } \\
\text { and nasogastric feeding) }\end{array}$ & & & & & $\begin{array}{l}\text { Performed in last } 3 \\
\text { months }\end{array}$ & \\
\hline Safe administration of oxygen & & & & & $\begin{array}{l}\text { Performed in last } 3 \\
\text { months }\end{array}$ & \\
\hline $\begin{array}{l}\text { Injectable antibiotics for } \\
\text { neonatal infection }\end{array}$ & & $\begin{array}{l}\text { Training in last } \\
24 \text { months }\end{array}$ & $\begin{array}{l}\text { Practiced in } \\
\text { last } 12 \text { months }\end{array}$ & & $\begin{array}{l}\text { Performed in last } 3 \\
\text { months }\end{array}$ & $\begin{array}{l}\text { Ever received } \\
\text { training }\end{array}$ \\
\hline Intravenous fluid & & $\begin{array}{l}\text { Training in last } \\
24 \text { months }\end{array}$ & & & $\begin{array}{l}\text { Performed in last } 3 \\
\text { months }\end{array}$ & \\
\hline
\end{tabular}

EmONC - Emergency Obstetric and Newborn Care, SPA - Service Provision Assessment, SARA - Service Availability and Readiness Assessment 
The synthesis of these findings to provide recommendations on improving these measurements is provided in the Discussion section.

\section{DISCUSSION}

We have mapped the service readiness requirements for inpatient newborn care, detailing a total of 654 structural components to deliver 17 newborn interventions. Our review of three health facility assessment tools identified measurement gaps for almost all newborn interventions, even for the more basic interventions, such as thermoregulation and feeding. The most significant measurement gaps are for more complex interventions, which are currently not captured by any of the tools in our review. We found many commonalities among these tools, but also highlighted important differences that show how they have evolved with important, but distinct purposes, and different measurement approaches [9]. The size and cost of these assessments already limits the frequency of carrying out these surveys; adding a long list of indicators for small and sick newborn care would compound this challenge [28]. To improve the existing tools, we found that a number of indicators for basic service readiness could be harmonised, and some proxy indicators of service readiness for more complex care could potentially be added. As with other more complex areas of care, monitoring all the structures and processes for small and sick newborns will likely require a facility-based monitoring system [29-31].

The existing, up-to-date care guidelines for inpatient care for small and sick newborns are mainly split between obstetric care and paediatric care (Table 2) [32-35]. To the best of our knowledge, this is the first time that service readiness for small and sick newborn care has been delineated and mapped by structural component. The resulting matrix can be used by implementers for programme planning, depending on the needs of their health system and the interventions or packages of care they intend to provide at their service (Table S1 in Online Supplementary Document). It is a step towards developing a more general facility based monitoring system or core module. Following validation, such a tool could be adapted for different settings as has been done in India [29].

The following sections provide a synthesis of findings and recommendations for improving the widely used tools for measurement of small and sick newborn care.

\section{Harmonisation of existing health facility assessment tools}

\section{Indicators}

The interventions that are best represented by the existing tools are those that have been promoted as vertical programmes, such as neonatal resuscitation (which is a core indicator for obstetric and newborn care assessments), essential newborn care (for all babies) and PMTCT. The measurement approach and indicators for many of the more basic newborn interventions would benefit from more standardisation between tools. As a minimum, this should include service readiness indicators for essential newborn care (including service readiness for drying, skin-to-skin contact, cord clamping, vitamin $\mathrm{K}$ and initiation of breastfeeding), neonatal resuscitation and kangaroo mother care [28].

All of the existing tools have some questions on KMC, but for monitoring of operational KMC [28], the facility inventories require adaptations to incorporate more of the items needed for KMC [23] including the equipment for feeding support, antibiotics and amenities for mothers to stay in the facility [14]. Whilst listing the items needed for antenatal care exceeded the scope of this exercise, these should be considered in future tools, such as availability of antenatal corticosteroids for threatened preterm labour and antibiotics for preterm rupture of membranes (per WHO guidelines) as a minimum.

Measurement of training and skills for newborn interventions could be harmonised between tools such that these indicators are comparable between different surveys (see Table 4).

\section{Crosscutting service readiness needs}

Health providers, especially midwives and specialist nurses, play a critical role in neonatal care $[6,8,36-$ 38]. Specially trained neonatal nurses may not be available in all health facilities, but previous studies show it is important to monitor who, if anyone, cares for newborns in the absence of specialised staff [8]. Recent studies in higher income settings, where neonatal nursing is a specialist cadre, show that reducing the nurse-to-patient ratio in neonatal units increases in-hospital mortality [39,40]. As a minimum, all health facility assessment survey tools could include questions on staff rotation policies to ensure specialist staff 
are not regularly being rotated to other areas of care [8], such a question is currently only included in the EmONC tool. Other allied and supportive professionals may be a necessary addition to the list of staff cadres, such as biomedical engineers for maintaining equipment and nursing support staff. For all health facility assessment tools, the capacity and readiness of a facility to provide referral to facilities that can provide more complex care for small and sick is a critical indicator of service readiness. The difficulty and inconsistency in measurement of provider skills and training also illustrates the need for further research into human resource tracking, and work to set benchmarks for staffing ratios for neonatal care [8].

Infection prevention and control is essential for all areas of the facility, with newborns particularly vulnerable, and most of the newborn deaths from infections occurring in small babies. The current tools have several general water and sanitation indicators, which should be harmonised across tools to ensure that the basic soap, running water and safe and effective antiseptics are available in labour and delivery and neonatal care areas. A standard indicator that measures whether the newborn space is separate from the paediatric ward, and for whether there is a system for inborn and out born babies could be a potential proxy indicator for service readiness.

\section{Measuring more complex inpatient care for small and sick newborns}

Small and sick babies, especially those born preterm, are at higher risk of multiple childhood morbidities (including visual, hearing and neuro-developmental), with increasing gradient of adverse developmental outcomes by lower gestational age of survivors $[41,42]$. These newborns often require more complex interventions, such as respiratory support (oxygen, continuous positive airway pressure), treatment of specific complications (feeding, seizures, jaundice), and screening and follow up services (Figure 1) $[8,43$ 47]. Many of these interventions carry a risk of harm when not performed with safe equipment or by trained staff. This is illustrated in middle-income settings, where we have seen an increase in impairments among survivors of neonatal care, especially where complex care has been scaled up without due attention to service readiness and quality of care $[41,42,48]$.

The existing tools do not capture the large number of items required to deliver complex interventions safely, which would require a facility based monitoring register that also includes process and outcome data (morbidity and mortality) [49]. Such registers have been developed in higher- and middle-income settings $[29,49]$, but are not standardised routine systems. Further research into adaptations of existing tools is an important next step.

Clinical care charts and protocols are essential for quality and safety of neonatal care that requires complex calculations of drug concentrations and specific diluents, dosages, and delivery modes for newborns. In addition to service readiness, the risks of certain interventions can be mitigated by ensuring clinical record keeping, which is known to be sub-standard in many settings [50]. Standardised observation charts for monitoring of vital signs (eg, hourly or three-hourly), fluid input and output, feeding method and volume, and monitoring medications and laboratory tests (eg, serum bilirubin and exchange transfusion thresholds) could support facilities, alongside up-to-date standardised evidence-based guidelines, a list of which is included in the documentation section of our matrix.

\section{Implications and next steps for monitoring service readiness for inpatient care of small and sick newborns}

Amongst existing partners and initiatives, there is widespread recognition of the need to harmonise monitoring systems for perinatal care. The existing EmOC signal functions do not represent the full set of facility-based interventions for mothers and newborns, and small and sick newborns are especially neglected. Given the large number of service readiness requirements for small and sick newborn care, a short list of signal functions for monitoring purposes is a potential solution. Previous work by Gabrysch and colleagues has recommended improvements to these tools [51]. Currently, a global survey led by Every Newborn partners, alongside a technical group led by AMDD and UNFPA are working on linking this to the emergency obstetric care indicators, with plans to finalise recommendations for newborn signal functions in 2018-2019 [9].

Periodic evaluation, using health facility surveys, is currently necessary, but ultimately the goal should be to incorporate such assessments into functional and sustainable routine national systems. These should operate independent of donor funding and project mandates. The current health facility assessment tools are costly and time-consuming. Lighter assessments that can be carried out more frequently are also required, and need more research [52]. Even in high-income countries, not all national facilities feed infor- 
mation into one database for national monitoring of inpatient care of small and sick newborns. Low- and middle-income countries that have not moved to electronic information systems have an advantage in that they can leap-frog the situation of having fragmented and discrepant electronic data collection forms which differ from facility to facility or region to region. Exploration of the potential use of DHIS-2 platforms for facility-based monitoring is being carried out as part of the Every Newborn metrics work on small and sick newborns [9]. This work supports the growing interest in use of routine health management information systems to monitor aspects of service delivery in facilities [14], and of logistic management information systems (LMIS) to track logistics and supplies.

\section{CONCLUSIONS}

Tracking of service readiness to provide inpatient care of small and sick newborns is needed to gain the required policy attention, accountability and investment that is critical to end preventable newborn deaths, and improve child development. This is reflected in the Global Strategy for Women, Children and Adolescents, the WHO Quality of Care Framework, and is supported by the Every Newborn metrics working group. The existing health facility assessments do not generate comparable data, and have very limited assessment of more complex care for small and sick newborns. Indicators in existing tools can be harmonised, but the size and cost of these assessments limits their frequency. Developing a core list of harmonised indicators for use in routine health information systems could help address this gap. Improvements in these monitoring systems are urgently needed to inform efforts to improve quality of care and investments in health systems scale-up, to end preventable newborn death and disability, alongside work to end preventable maternal deaths and stillbirths.

Acknowledgements: We would like to acknowledge the following clinicians for their careful review of the matrix (Table S1 in Online Supplementary Document): Dr Olukemi Oluwatoyin, Consultant Paediatrician, University College, Ibadan, Nigeria; Dr Ezeanosike Obumneme, Consultant Neonatologist, Federal Teaching Hospital, Abakaliki, Nigeria, Dr Nana Okai Brako, Paediatrician, Greater Accra Regional Hospital, Accra, Ghana and Dr Kojo Ahor-Essel, Paediatrician, Maud Essabah Fandoh, Nurse, Neonatal Intensive Care and Afua Antiwiwaa Ofori, Nurse, Neonatal Intensive Care, Korle Bu Teaching Hospital, Accra, Ghana. Thank you also to the Every Newborn metrics team for support in the organisation of this work. We would like to acknowledge the important contribution of the participants at the April 2016 Every Newborn metrics workshop in the session on inpatient care for small and sick newborns: Lara Vaz, Juan Dewez, Ehsan Rahman, Queen Dube, Nalini Singhal, Anne-Marie Bergh, Michel Brun, Mary Azayo, Steve Wall, Rubayet Sayet, Indira Narayanan, Al Ayede and Goldy Mazia; and Georgia Gore-Langton for her detailed notes. Thank you to Matthews Mathai and Ashok Deorari who could not attend the session, but provided comments on the process. Thank you to Claire Gilbert for her assistance with retinopathy of prematurity guidelines and the laboratory team at University College Hospital, London. Thanks to Sarindi Aryasinghe and Victoria Ponce-Hardy at LSHTM for their assistance with formatting figures and tables. Finally, thank you to Bina Valsangkar and the Save the Children's Saving Newborn Lives programme for their overall coordination of this supplement.

Funding: Publication costs for this supplement and some of the time for SM were funded by Save the Children's Saving Newborn Lives programme. The Every Newborn measurement improvement work coordinated by the London School of Hygiene \& Tropical Medicine (LSHTM) is funded by the Children's Investment Fund Foundation (CIFF).

Authorship declaration: SGM, TG and JL were responsible for the conceptualisation of the paper. SGM was responsible for carrying out the review of the tools, the conceptualisation and collation of the matrix, the writing process, coordination of paper drafts and design of the figures and tables. TG reviewed early drafts of the manuscript. A representative of the lead agency for each of the tools then verified the review of the tools. OC and JL provided oversight of the final drafts of the paper. All named authors reviewed drafts of the paper and approved the final manuscript.

Competing interests: The authors have completed the Unified Competing Interest form at www.icmje.org/coi_ disclosure.pdf (available on request from the corresponding author) and declare no conflict of interest).
} 
1 UN-IGME. Levels and trends in child mortality: Report 2017. UNICEF; WHO; World Bank Group; United Nations, 2017.

2 World Health Organization. MCEE-WHO methods and data sources for child causes of death 2000-2015. Geneva, Switzerland: Department of Evidence Geneva); 2016.

3 Bhutta ZA, Das JK, Bahl R, Lawn JE, Salam RA, Paul VK, et al. Can available interventions end preventable deaths in mothers, newborn babies, and stillbirths, and at what cost? Lancet. 2014;384:347-70. Medline:24853604 doi:10.1016/ S0140-6736(14)60792-3

4 Wall SN, Lee AC, Niermeyer S, English M, Keenan WJ, Carlo W, et al. Neonatal resuscitation in low-resource settings: what, who, and how to overcome challenges to scale up? Int J Gynaecol Obstet. 2009;107 Suppl 1:S47-62. Medline:19815203 doi:10.1016/j.ijgo.2009.07.013

5 Enweronu-Laryea C, Dickson KE, Moxon SG, Simen-Kapeu A, Nyange C, Niermeyer S, et al. Basic newborn care and neonatal resuscitation: a multi-country analysis of health system bottlenecks and potential solutions. BMC Pregnancy Childbirth. 2015;15 Suppl 2:S4. Medline:26391000 doi:10.1186/1471-2393-15-S2-S4

6 Lawn JE, Davidge R, Paul VK, von Xylander S, de Graft Johnson J, Costello A, et al. Born too soon: care for the preterm baby. Reprod Health. 2013;10 Suppl 1:S5. Medline:24625233 doi:10.1186/1742-4755-10-S1-S5

7 World Health HO. UNICEF. Every Newborn: An action plan to end preventable newborn deaths Geneva: World Health Organisation2014. Available: http://www.everynewborn.org/every-newborn-action-plan/. Accessed: 1 September 2014.

8 Moxon SG, Lawn JE, Dickson KE, Simen-Kapeu A, Gupta G, Deorari A, et al. Inpatient care of small and sick newborns: a multi-country analysis of health system bottlenecks and potential solutions. BMC Pregnancy Childbirth. 2015;15 Suppl 2:S7. Medline:26391335 doi:10.1186/1471-2393-15-S2-S7

9 World Health Organization, London School of Hygiene and Tropical Medicine. Every Newborn Action Plan Metrics: Design workshop for facility based testing of coverage metrics. 2016. Available: http://www.healthynewbornnetwork. org/hnn-content/uploads/ENAP-Metrics-Facility-based-Workshop-Report_April-2016_FINAL.pdf. Accessed: 1 September 2017.

10 Donabedian A. The quality of care. How can it be assessed? JAMA. 1988;260:1743-8. Medline:3045356 doi:10.1001/ jama.1988.03410120089033

11 Donabedian A. Some basic issues in evaluating the quality of health care. ANA Publ. 1976;(G-124):3-28. Medline:826182

12 Donabedian A. Evaluating the quality of medical care. Milbank Mem Fund Q. 1966;44 Suppl:166-206. Medline:5338568 doi:10.2307/3348969

13 Lawn JE, Blencowe H, Oza S, You D, Lee AC, Waiswa P, et al. Every Newborn: progress, priorities, and potential beyond survival. Lancet. 2014;384:189-205. Medline:24853593 doi:10.1016/S0140-6736(14)60496-7

14 Moxon SG, Ruysen H, Kerber KJ, Amouzou A, Fournier S, Grove J, et al. Count every newborn; a measurement improvement roadmap for coverage data. BMC Pregnancy Childbirth. 2015;15 Suppl 2:S8. Medline:26391444 doi:10.1186/1471-2393-15-S2-S8

15 Kerber KJ, Mathai M, Lewis G, Flenady V, Erwich JJ, Segun T, et al. Counting every stillbirth and neonatal death through mortality audit to improve quality of care for every pregnant woman and her baby. BMC Pregnancy Childbirth. 2015;15 Suppl 2:S9. Medline:26391558 doi:10.1186/1471-2393-15-S2-S9

16 Requejo J, Victora C, Bryce J. A Decade of Tracking Progress for Maternal, Newborn and Child Survival: The 2015 Report. 2015. Available: http://www.countdown2015mnch.org/documents/2015Report/Countdown_to_2015-A_Decade_ of_Tracking_Progress_for_Maternal_Newborn_and_Child_Survival-The2015Report-Conference_Draft.pdf. Accessed: 1 September 2017

17 Bryce J, Arnold F, Blanc A, Hancioglu A, Newby H, Requejo J, et al. Measuring coverage in MNCH: new findings, new strategies, and recommendations for action. PLoS Med. 2013;10:e1001423. Medline:23667340 doi:10.1371/journal. pmed.1001423

18 Stanton CK, Rawlins B, Drake M, Dos Anjos M, Cantor D, Chongo L, et al. Measuring coverage in MNCH: testing the validity of women's self-report of key maternal and newborn health interventions during the peripartum period in Mozambique. PLoS One. 2013;8:e60694. Medline:23667427 doi:10.1371/journal.pone.0060694

19 O'Neill K, Takane M, Sheffel A, Abou-Zahr C, Boerma T. Monitoring service delivery for universal health coverage: the Service Availability and Readiness Assessment. Bull World Health Organ. 2013;91:923-31. Medline:24347731 doi:10.2471/BLT.12.116798

20 World Health Organization. Service Availability and Readiness Assessment (SARA): an annual monitoring system for service delivery: Reference Manual. 2015. Available: http://www.who.int/healthinfo/systems/sara_reference_manual/en/. Accessed: 1 September 2017.

21 AMDD. Averting Maternal Death and Disability (AMDD) 2017. Available: https://www.mailman.columbia.edu/research/ averting-maternal-death-and-disability-amdd. Accessed: 9 April 2018.

22 United Nations Population Fund. https://www.unfpa.org/. Accessed: 9 April 2018.

23 Vesel L, Bergh AM, Kerber KJ, Valsangkar B, Mazia G, Moxon SG, et al. Kangaroo mother care: a multi-country analysis of health system bottlenecks and potential solutions. BMC Pregnancy Childbirth. 2015;15 Suppl 2:S5. Medline:26391115 doi:10.1186/1471-2393-15-S2-S5

24 World Health Organization. Interagency list of medical devices for reproductive, maternal, newobrn and child health. Geneva; World Health Organization: 2015.

25 UNICEF. Children St. Newborn Health in Humanitarian Settings: A Field Guide (Interim Version). United Nations2016.

26 World Health Organization. WHO Model List of Essential Medicines (20th list); amended August 2017. Available: http:// www.who.int/medicines/publications/essentialmedicines/20th_EML2017_FINAL_amendedAug2017.pdf?ua=1. Accessed: 1 September 2017. 
27 Program DHS. Service Provision Assessments Calverton, MD, USA: ICF Macro; 2014. Available: http://www.measuredhs.com/What-We-Do/Survey-Types/SPA.cfm. Accessed: 1 November 2011.

28 Madaj B, Smith H, Mathai M, Roos N, van den Broek N. Developing global indicators for quality of maternal and newborn care: a feasibility assessment. Bull World Health Organ. 2017;95:445-52I. Medline:28603311 doi:10.2471/ BLT.16.179531

29 Neogi SB, Khanna R, Chauhan M, Sharma J, Gupta G, Srivastava R, et al. Inpatient care of small and sick newborns in healthcare facilities. J Perinatol. 2016;36 s3:S18-23. Medline:27924106 doi:10.1038/jp.2016.186

30 Neogi SB, Malhotra S, Zodpey S, Mohan P. Challenges in scaling up of special care newborn units-lessons from India. Indian Pediatr. 2011;48:931-5. Medline:22253148 doi:10.1007/s13312-011-0149-z

31 Neogi SB, Malhotra S, Zodpey S, Mohan P. Assessment of special care newborn units in India. J Health Popul Nutr. 2011;29:500-9. Medline:22106756 doi:10.3329/jhpn.v29i5.8904

32 World Health Organization. Managing complications in pregnancy and childbirth: a guide for midwives and doctors. Geneva: World Health Organization; 2000.

33 World Health Organization. Pregnancy, Childbirth, Postpartum and Newborn Care: A guide for essential practice. Geneva: World Health Organization; 2006.

34 World Health Organization. Management of newborn problems: a guide for doctors, nurses and midwives. Geneva: World Health Organization; 2003.

35 World Health Organization. Pocket book of hospital care for children: Guidelines of the management of common childhood illnesses. Geneva: World Health Organization; 2013.

36 Premji SS, Spence K, Kenner C. Call for neonatal nursing specialization in developing countries. MCN Am J Matern Child Nurs. 2013;38:336-42. Medline:23792874 doi:10.1097/NMC.0b013e31829f2c94

37 Kalyan G, Moxon S. The role of neonatal nurses in the prevention of retinopathy of prematurity. Indian Pediatr. 2016;53 Suppl 2:S143-50. Medline:27915323

38 Kalyan G, Vatsa M. Neonatal nursing: An unmet challenge in India. Indian J Pediatr. 2014;81:1205-11. Medline:25278279 doi:10.1007/s12098-014-1567-4

39 Watson SI, Arulampalam W, Petrou S, Marlow N, Morgan AS, Draper ES, et al. The effects of a one-to-one nurse-to-patient ratio on the mortality rate in neonatal intensive care: a retrospective, longitudinal, population-based study. Arch Dis Child Fetal Neonatal Ed. 2016;101:F195-200. Medline:26860480 doi:10.1136/archdischild-2015-309435

40 Hamilton KE, Redshaw ME, Tarnow-Mordi W. Nurse staffing in relation to risk-adjusted mortality in neonatal care. Arch Dis Child Fetal Neonatal Ed. 2007;92:F99-103. Medline:17088341 doi:10.1136/adc.2006.102988

41 Blencowe H, Lawn JE, Vazquez T, Fielder A, Gilbert C. Preterm-associated visual impairment and estimates of retinopathy of prematurity at regional and global levels for 2010. Pediatr Res. 2013;74 Suppl 1:35-49. Medline:24366462 doi:10.1038/pr.2013.205

42 Blencowe H, Lee AC, Cousens S, Bahalim A, Narwal R, Zhong N, et al. Preterm birth-associated neurodevelopmental impairment estimates at regional and global levels for 2010. Pediatr Res. 2013;74 Suppl 1:17-34. Medline:24366461 doi:10.1038/pr.2013.204

43 Bhutani VK, Cline BK, Donaldson KM, Vreman HJ. The need to implement effective phototherapy in resource-constrained settings. Semin Perinatol. 2011;35:192-7. Medline:21641494 doi:10.1053/j.semperi.2011.02.015

44 Bhutani VK, Maisels MJ, Stark AR, Buonocore G. Management of jaundice and prevention of severe neonatal hyperbilirubinemia in infants >or=35 weeks gestation. Neonatology. 2008;94:63-7. Medline:18204221 doi:10.1159/000113463

45 Slusher TM, Zipursky A, Bhutani VK. A global need for affordable neonatal jaundice technologies. Semin Perinatol. 2011;35:185-91. Medline:21641493 doi:10.1053/j.semperi.2011.02.014

46 Luu MN, Le LT, Tran BH, Duong TK, Nguyen HT, Le VT, et al. Home-use icterometry in neonatal hyperbilirubinaemia: Cluster-randomised controlled trial in Vietnam. J Paediatr Child Health. 2014;50:674-9. Medline:24888540 doi:10.1111/ jpc. 12611

47 Kumar P, Chawla D, Deorari A. Light-emitting diode phototherapy for unconjugated hyperbilirubinaemia in neonates. Cochrane Database Syst Rev. 2011;12:CD007969. Medline:22161417

48 Blencowe H, Vos T, Lee AC, Philips R, Lozano R, Alvarado MR, et al. Estimates of neonatal morbidities and disabilities at regional and global levels for 2010: introduction, methods overview, and relevant findings from the Global Burden of Disease study. Pediatr Res. 2013;74 Suppl 1:4-16. Medline:24366460 doi:10.1038/pr.2013.203

49 Horbar JD, Soll RF, Edwards WH. The Vermont Oxford Network: a community of practice. Clin Perinatol. 2010;37:2947. Medline:20363446 doi:10.1016/j.clp.2010.01.003

50 Musiime GM, Seale AC, Moxon SG, Lawn JE. Risk of gentamicin toxicity in neonates treated for possible severe bacterial infection in low- and middle-income countries: Systematic review. Trop Med Int Health. 2015;20:1593-606. Medline:26426298 doi:10.1111/tmi.12608

51 Gabrysch S, Civitelli G, Edmond KM, Mathai M, Ali M, Bhutta ZA, et al. New signal functions to measure the ability of health facilities to provide routine and emergency newborn care. PLoS Med. 2012;9:e1001340. Medline:23152724 doi:10.1371/journal.pmed.1001340

52 UNFPA. Improving obstetric and neonatal care: implementation manual for developing a national network of referral maternity facilities. (In press). New York: UNFPA. 